\title{
State Sovereignty Claims for the Dealing with Sea Boundary Disputes
}

\author{
Popi Tuhulele*, Marcel Hendrapati, Syamsuddin Muhammad Noor, Muhammad Ashri
}

Faculty of Law, Hasanuddin University, South Sulawesi, Indonesia

DOI: $10.36348 /$ sijlcj.2020.v03i11.007

| Received: 01.11.2020 | Accepted: 09.11.2020 | Published: 16.11 .2020

*Corresponding author: Popi Tuhulele

\section{Abstract}

Global developments and trends are one of the factors that greatly influence the dynamics of regional security. The issue of regional security is still covered by potential conflicts, such as territorial sovereignty claims, transnational security threats, interstate conflicts based on territorial claims and maritime security. The research is a normative-juridical research, using a statute, conceptual and case approaches. The results show that the unilateral claim of Indonesia for delimiting sea boundaries with neighboring countries is an act that has legal legality, because it is done based on the provisions of the convention. The construction of dispute resolution over overlapping claims on the borders of Indonesia' maritime territory with neighboring countries, it can be concluded that the determination of delimitation of sea territory between archipelagic countries such as Indonesia and coastal States must provide a just solution for countries. In determining the delimitation of sea boundaries between archipelagic countries such as Indonesia and neighboring countries, it must be based on the fairness principle by considering political, legal and technical aspects to achieve an equitable solution while still considers special or relevant circumstances.

Keywords: International Law; Legal Enforcement; Sea Boundary Disputes; State Sovereignty.

Copyright $\odot \mathbf{2 0 2 0}$ The Author(s): This is an open-access article distributed under the terms of the Creative Commons Attribution 4.0 International License (CC BY-NC 4.0) which permits unrestricted use, distribution, and reproduction in any medium for non-commercial use provided the original author and source are credited.

\section{INTRODUCTION}

The recent heightening of the competition between China and its neighbors over sovereignty, resources, and security in the South China Sea has drawn the attention of diplomatic and military leaders from many countries that $\operatorname{seek}\left[{ }^{1}\right]$. The news is always related to the increase of security and politics escalation in the Asia Pacific region. This is triggered by the unilateral actions of the State in relation to territorial sovereignty claims in sea areas, islands and maritime boundaries with neighboring countries[ ${ }^{2}$ ]. This unilateral claim is responded to by neighboring countries facing or adjacent by filing protests as a form of objection, also claiming sovereignty over the disputed territory and even military confrontation if the action is considered a territorial violation.

\footnotetext{
${ }^{1}$ Dutton, Peter. 2011. Three disputes and three objectives: China and the South China Sea. Naval War College Review, 64(4), 42-67.

${ }^{2}$ Buga, Irina. 2012. Territorial sovereignty issues in maritime disputes: a jurisdictional dilemma for law of the sea tribunals. The International Journal of Marine and Coastal Law, 27(1), 59-95.
}

At the regional scope, global developments and trends are one of the factors that greatly influence the dynamics of regional security. The issue of regional security is still covered by potential conflicts, such as territorial sovereignty claims, transnational security threats, interstate conflicts based on territorial claims and maritime security, especially sea communication and trade routes by sea $\left[{ }^{3}\right]$.

A number of border disputes that have not been fully resolved that have surfaced in the region among others China' territorial sovereignty claims over the South China Sea, by publishing a map that marks nine dashed lines in almost all parts of the South China Sea area $\left[{ }^{4}\right]$. It causes a conflict in the South China Sea that involved several countries, i.e China, Vietnam, the Philippines, Malaysia, Taiwan and Brunei Darussalam. The border dispute that occurred in the South China Sea is a claim of ownership over two main islands in the

\footnotetext{
${ }^{3}$ Dephan, 2008, Buku Putih Pertahanan Indonesia, Depertemen Pertahanan Republik Indonesia, pp 15-16

${ }^{4}$ Evelyn Goh, 2005, Meeting the China Challenge: The U.S. in Southeast Asian Regional Security Strategies, East-West Center Washington, p. 31
} 
South China Sea, namely Spratly and Paracels $\left[{ }^{5}\right]$. Overlapping claim over the islands and sea areas around Spartly and Paracels Islands that has led to an increase in security and policy escalation in the region in recent years because it has involved countries outside the region.

On the other hand, there are several waters that have the potential to become conflict in the Southeast Asian waters, apart from the South China Sea, i.e Andaman Sea, Thailand gulf, Tonkin gulf, Malacca Strait, Sulawesi Sea, Sulu Sea, Arafura Sea, Timor Sea and Torres Strait. The claims of countries over these waters concern the territorial sea, the continental shelf and the Exclusive Economic Zone. Nine out of ten members of the Association of Southeast Asian Nations (ASEAN) are claimants of this sea area. It creates border disputes as a real threat to Southeast Asia' maritime security $\left[{ }^{6}\right]$.

Indonesia as an archipelago in the Southeast Asia region has a unique geographical position and making it strategic. This position places Indonesia directly bordering the sea, land and air with ten countries in the region. Indonesia also has unresolved problems in the maritime border area. Indonesia has potential maritime claims that overlap with ten neighboring countries, namely India, Thailand, Malaysia, Singapore, Vietnam, Philippines, Palau, Papua New Guinea, Australia and Timor Leste $\left[{ }^{7}\right]$ By these geographic characteristics, it is important for Indonesia to maintain a relationship of mutual respect, especially in matters of State territory as a form of respect for the integrity and sovereignty of the country $\left[{ }^{8}\right]$.

${ }^{5}$ Ralf Emmers, Maritime Dispute in The South China Sea; Stategic and Diplomatic Status Guo, Institute of Defince and Stategic Studies, Singapura, September 2005, p.1

${ }^{6}$ Paulus Londo, Sengketa Perbatasan Antar Negara dikawasan Asia Pasific, Accessed March 12, 2018 at: http://www.tnial.mil.id/TroopInfo/PeneranganPasukan/t abid/104/articleType/ArticleView/articleId/42/Default.a spx

${ }^{7}$ Avas. H. Oegroseno, 2009, Indonesia's Maritime Boundaries, as cited in Cribb, R. and Ford, M. (eds) Indonesia Beyond the Water's Edge - Managing an Archipelagic State, ISEAS, Singapore. p.2

${ }^{8}$ Magassing, A., Patittingi, F., Alwy, S., Hambali, R., Sumardi, J., Kadarudin, \& Hendrapati, M. (2018). The removal of offshore installation in indonesian national regulation. Journal of East Asia and International Law, 11(1), 183-192. doi:10.14330/jeail.2018.11.1.09
In Indonesia, the implementation of territorial sovereignty is not easy in relation to bordering countries. This is due to the complexity of determining borders between countries. The unresolved problems of Indonesia maritime boundaries with neighboring countries, among others, the dispute between Indonesia and Malaysia regarding a part of the Sulawesi Sea to the east of Kalimantan called Ambalat (Ambalat offshore area) appeared for the first time in February-March $2005\left[{ }^{9}\right]$. Ambalat is a seabed block by $15,235 \mathrm{~km}^{2}$ located in the east of Kalimantan Island on the offshore area with a depth between 1.000 to 2.375 meters below sea level on the continental shelf of Kalimantan. Ambalat block is a natural continuation of the mainland of Kalimantan Indonesian, the base rock is part of the continental plate forming Kalimantan $\left[{ }^{10}\right]$. According to C. Schofield and I. Storey $\left[{ }^{11}\right]$. Ambalat is a seabed block that is in ZEE regime and the continental shelf, it means that it is not under a sovereignty regime, but rather sovereign rights.

In the perspective of Indonesia, Malaysia has claimed an area previously managed by Indonesia. The dispute of Ambalat block is not about state sovereignty but overlapping claims on the continental shelf and ZEE in which the both countries have specific sovereign rights $\left[{ }^{12}\right]$.
${ }^{9}$ C.P.F. Luhulima,2011, Dinamika Asia Tenggara Menuju 2015, Pustaka Pelajar, Yogjakarta, p. 146.

${ }^{10}$ Dewi Dwi Puspita Sari S, Etty Eidman, Luky Adrianto, Studi Analisis Konflik Ambalat Perairan Sulawesi, Buletin Ekonomi Perikanan Vol. VIII, No. 2 Tahun 2008, p. 44

${ }^{11}$ C. Schofield and I. Storey, 2005, Energy Security and Southeast Asia: The Impact on Maritime Boundary and Territorial Disputes. Harvard Asia Quarterly Journal, Vol.9, No.4

${ }^{12}$ Bambang Cipto, 2010, Hubungan Internasional di Asia Tenggara, Pustaka Pelajar, Yogyakarta, p. 203. 


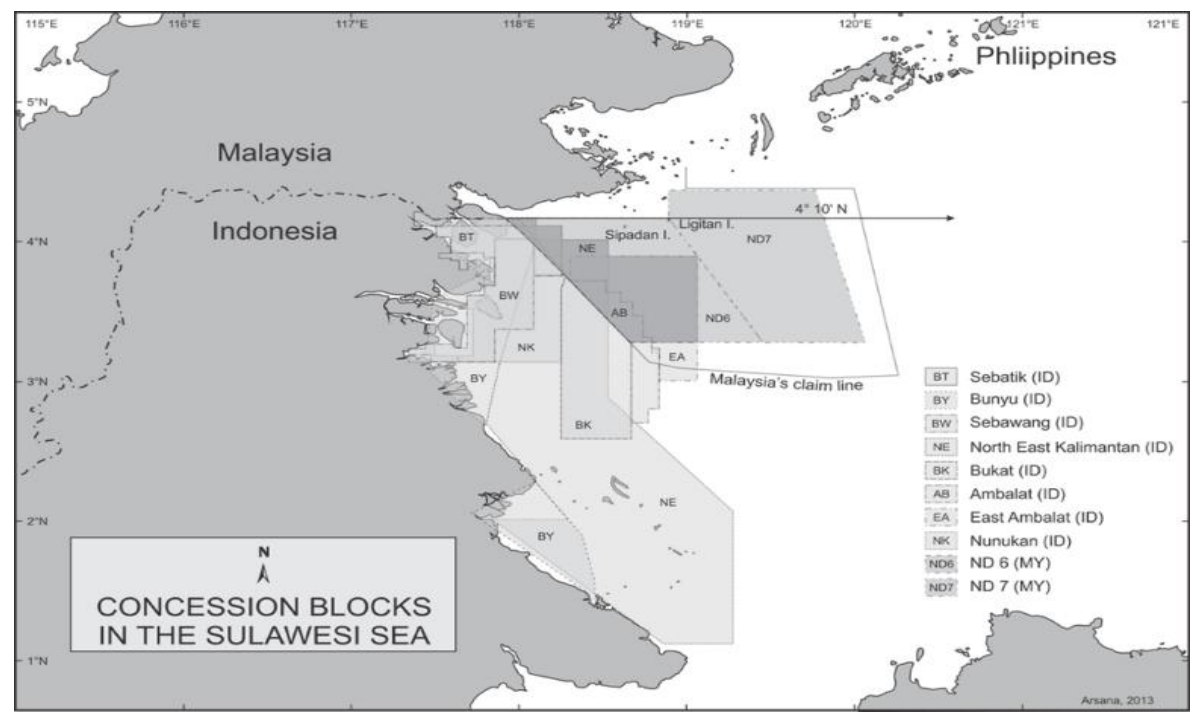

Fig-1: Location illustration of Ambalat block

Source: Primary data, 2020 (edited)

On the other hand, Malaysia' territorial sea boundary in the northern part of Malacca strait still leaves problems with Indonesia. Malaysia is not an archipelagic country, but in determining the marine zone of Malaysia applies the principles of drawing a straight archipelago between Jara and Perak Islands, has a distance 123 nautical miles. The baseline is used as the basis for determining the width of the territorial sea as far as 12 nautical miles towards the sea, and causes a part of Indonesia's ZEE into Malaysian territorial sea $\left[{ }^{13}\right]$.

The problem of geographic causes overlapping claims with other countries. These overlapping claims in some instances led to confrontations with other countries. Although Indonesia always emphasizes efforts to resolve peacefully in every maritime boundary problem with neighboring countries. Hence, it is important to accelerate the settlement of maritime border disputes. Unresolved maritime boundaries can hinder and harm economic activity, on the other hand, unclear and unresolved border points will create potential new disputes between Indonesia and neighboring countries $\left[{ }^{14}\right]$.

\section{METHOD OF RESEARCH}

The research is a normative-juridical research, using a statute, conceptual and case approaches $\left[{ }^{15}\right]$.

13 Danar Widyananta, 2012, Masalah Penetapan Batas Landas Kontinen dan Zone Ekonomi Eksklusif (ZEE) Indonesia, Jurnal Mozaik, Vol. 6, No. I, p.43

${ }^{14}$ DPD RI, the Draft of Views and Opinions of the Regional Representative Council of the Republic of Indonesia against the Draft of State Territory Bill, Jakarta March 3, 2008, p. 2

15 Irwansyah, 2020, Penelitian Hukum; Pilihan Metode \& Praktik Penulisan Artikel, Mirra Buana Media, Yogyakarta, p. 61-63
Research instruments as a means of collecting legal materials are obtained through literature study, legislation and interviews. Existing data from various sources were analyzed by using content analysis techniques.

\section{Sovereignty Claim of Indonesia Territorial as an Archipelagic Country upon Delimitation of State Territory at Sea: A Case Study}

Indonesia as an archipelago that is multi-ethnic and multilingual, having sovereignty over the islands is important to achieve national unity $\left[{ }^{16}\right]$. The extent of Indonesia' territorial sovereignty shows the long history of Indonesia diplomatic campaign for more than two decades struggling for the concept of an archipelago nation and ultimately it is adopted as a regime in 1982 UNCLOS. Since 1969, Indonesia has negotiated its maritime boundaries with neighboring countries, including Australia, India, Malaysia, Singapore and Thailand. On various occasions, Indonesia compromised with neighboring countries, giving them a larger share of the disputed territory to use the basic points defined in Act No.4 of 1960, in an attempt to gain implicit recognition of the archipelago concept $\left[{ }^{17}\right]$.

16 Geospatial Information Agency, Marine Reference Data of the Republic of Indonesia. Accessed on

http://www.big.go.id/assets/download/2017/NKRI2017/ Peta_NKRI_Skala_5000000_03102017.pdf on 9 August 2019.

${ }^{17}$ Zhen Sun, Book Review: How Indonesia became an archipelagic state in 'Sovereignty and the Sea' By John G. Butcher and R.E. Elson, The Jakarta Post, 23 June 2017 accessed on https://www.thejakartapost.com/academia/2017/06/22/b ook-review-how-indonesia-became-an-archipelagicstate-in-sovereignty-and-the-sea.html on 9 August 2019 
Legally, Indonesia adopted the principle of an archipelago State in 1957 and 1962, initially other ASEAN's countries did not accept it. ASEAN countries ask that their interests be considered by this island nation. By the approval of the 1982 UNCLOS and the concept of their island nation, finally agreed to the implementation $\left[{ }^{18}\right]$. For this reason, Indonesia is conducting negotiations to resolve border problems with neighboring countries as well as seeking recognition and support for the concept of an archipelago that is being fought for. At that time, several agreements were indeed a mutually beneficial balanced package.

Indonesia' efforts to define maritime boundaries based on the 1982 UNCLOS have not always been easy. In determining maritime boundaries, international law has provided a reference. The problem is different views and understandings make the meaning of international maritime law different for each country. On the other hand, delimitation of maritime boundaries is a series of long processes ranging from political decisions to legal binding. When a country claims ownership of an area (political decisions) that falls under its sovereignty, it will face this legal process. This can be seen from the differences in views and claims over maritime boundary areas that occur between Indonesia and bordering countries.

In many cases the application of the provisions of the convention results in territorial seas, ZEE and the continental shelf of countries facing each other or side by side can overlap either actual or potential $\left[{ }^{19}\right]$. If this happens, international law has prepared a mechanism for resolving maritime boundary disputes, by prioritizing peaceful dispute resolution. Among other things, the countries concerned can seek mutual agreement related to overlapping claims in maritime zones that are mutually disputed through negotiations.

If in negotiation, the countries do not reach an agreement, the solution will be to involve a third party approved by the disputing countries. The use of maritime boundary dispute resolution procedures with the assistance of third parties can be through the State or figures as third parties, through judicial institutions or arbitration. The procedure for resolving maritime boundaries disputes always takes a very long time. As an alternative option before an agreement is made to

18 C. P.F. Luhulima, Permasalahan Batas Laut Antarnegara ASEAN dan Saran Penyelesaian, Jurnal Hukum dan Pembangunan, Vol. 20 No. 5 Oktober 1990, p.440

19 Marcel Hendrapati, 2013, Implikasi Keputusan Mahkamah Internasional Mengenai Kasus Pulau-Pulau Sipadan Dan Ligitan Terhadap Titik Pangkal Dan Delimitasi Maritim (Kajian Hukum Internasional), Dissertation: Graduate School, Hasanuddin University, resolve maritime boundary disputes between countries is to jointly use maritime boundaries that have not been determined.

Maritime border territories that are claimed and disputed ultimately belong to one of the bordering countries or even divided among these countries. For this reason, the identification of a dispute is very important to contribute in determining cooperation arrangements between the countries related to the dispute. In many cases maritime boundary delimitation disputes are resolved by compromise between the parties. Mutual compromises between the parties can reduce and/or eliminate differences between the parties in the application and interpretation of the convention content. Compromise between countries can be made with certain arrangements, both in the fields of security, utilization of fishery resources, environmental protection and law enforcement in maritime areas as well as by establishing cooperation zones for development of disputed parts.

Sea territory that has not been defined is a part of the border areas of opposite or adjacent countries where the both countries have different encapsulation in the application of conventions or differences in the determination of geographic base points as the basis for measuring the maritime zone of the country's jurisdiction. This difference results in overlapping claims between border countries. It is difficult to imagine how the interests of these competing nations can be reconciled and reach a compromise, in a world where public international law is relatively powerless, but an approach based on economic benefits can offer solutions going forward. Mineral resources under the sea are one of the main points of dispute, so utilization in the form of a Joint Development Zone (JDZ) has the potential to be made to manage this fairly. On the other hand, the awareness of countries today to utilize natural resources in a sustainable manner can also be a solution for fair use and management among countries. Because it concerns the sovereignty of the coastal States concerned, the adjustment of overlapping claims from ZEE or the continental shelf is very difficult, so that the problem of delimiting or dividing the areas of overlapping claims is unlikely to be resolved in the short time. However, if the countries concerned have the desire to put aside the issue of delimitation for the time being for the sake of prospective economic gain to be gained from a temporary compromise. They have the opportunity to arrange a joint development scheme. It is also possible to reduce the tension between them with such temporary measures at least for certain time period $\left[{ }^{20}\right]$.

\footnotetext{
${ }^{20}$ Masahiro Miyoshi, 1999, The Joint Development of Offshore Oil and Gas in Relation to Maritime Boundary Delimitation, International Boundaries Research Unit, Maritime Briefing, Vol. 2 No, 5, pp.151
} 
In recent years, the Joint Development Zone or JDZ and joint management has become the alternative resolution chosen by countries. The maritime JDZ has emerged as an important means of overcoming deadlocks related to maritime jurisdiction claims. A key consideration in negotiations and the establishment of maritime joint development arrangements is a precise definition of the geographic territory in which joint development will continue $\left[{ }^{21}\right]$. Broadly agreed maritime zones apart from maritime boundaries, these joint zones are defined in the absence of a maritime boundary which proves that the joint development zone is now a more popular alternative. Many of these joint zones are defined by the boundaries of competing maritime claims and thus involve the joint development of disputed water areas.

On the one hand, the use of joint maritime zones is often a sensitive and challenging issue. This occurs because without prejudice to the clause though the use of unilateral maritime claims as joint territorial boundaries to the extent of validating these claims has an impact on the State. This has resulted in the reluctance of some countries to, in a certain sense, acknowledge and accept what are considered to be excessive claims through their use in the definition of maritime joint development zone $\left[{ }^{22}\right]$.

Before further discussing the utilization of maritime boundaries that have not been determined by means of a joint development zone, it is necessary to see what is meant by a joint zone. Joint zone has been defined as the determination of joint maritime boundaries between the parties. In this case, the joint zone can act as a catalyst for reaching agreement on the delimitation line. For example, giving both parties a right in the maritime sector they want and therefore have the potential to answer potential drawbacks in delineation $\left[{ }^{23}\right]$.

On the other hand, the concept of joint development is a concept that has been widely used by countries, but until now there has been no agreement among experts on what the definition of this joint development. According to Masahiro Miyoshi, joint development is an intergovernmental arrangement that is temporary, and it is designed for the functional purpose of joint exploration for and/or exploitation of hydrocarbon resources from the seabed outside the territorial sea $\left[{ }^{24}\right]$. This definition is very narrow, however, referring to the agreement between Nigeria and the Republic of Sao Tome and Principe, it is a joint development zone agreement for exploration and exploitation of oil and fisheries resources in disputed territories. Another definition of joint development is

\footnotetext{
${ }^{21}$ Clive Schofield, 2014, Op Cit

${ }^{22}$ Ibid

${ }^{23}$ Ibid, pp.3-4

${ }^{24}$ Masahiro Miyoshi, OP Cit, p, 3
}

related to the context of defining territorial boundaries and sovereign rights, it means cooperation between countries to develop and share certain resources in certain zones, in relation to the two countries claiming rights. The zone where this cooperation occurs is joint development zone.

Joint development zone (JDZ) usually applies where the sea boundary has to be recovered. The second, JDZ is intended as a solution to assist coastal States to continue exploitation of good marine resources crosses their maritime boundaries, or is subject to conflicting claims when there are no boundaries. By JDZ, the State avoids or rapidly resolves disputes arising over these resources, thus allowing for exploration or exploitation under better conditions.

These means are similar to completely setting aside the claims of two countries, as explained by Ibrahim F. Shihata and William T. Onorato. The more difficult case, of course is where no boundary agreement has been reached. In fact, the joint development is a procedure whereby border disputes are set aside, without alleviate to the validity of conflicting claims, and conversely the interested countries agree to jointly explore and exploit and to share any hydrocarbons found in areas experiencing overlapping claims $\left[{ }^{25}\right]$.

Joint development is a concept that relates to the determination of maritime boundaries between related countries, based on mutual agreement to create cooperation between countries for the joint use of natural resources that cross disputed national borders which are called Joint Development Zones. This characteristic shows that joint development is not only applied to the exploitation of non-living resources but can also be applied to the exploitation of biological resources and others.

\section{Dispute Resolution of Overlapping Claim: Delimitation as a Principle in Designating Sea Territories}

A country can choose to alliance or jointly with any country if suitable, but due to the geographic location of a country it cannot be moved, then a country cannot choose its neighboring country. Therefore, a country must be able to live side by side with neighboring countries around its borders. Then, this fact is important for countries in Southeast Asia to maintain good relations between countries $\left[{ }^{26}\right]$.

International relations between countries, countries with individuals or countries with international organizations are not always well-

\footnotetext{
${ }^{25}$ Ibid

26 Evi Fitriani, 2012, Hubungan IndonesiaSingapura dalam Prespektif Sosial,Budaya, Negara dan Media, UI-Perss, Jakarta, p.11
} 
established. Often the relationship creates disputes between them $\left[{ }^{27}\right]$. A dispute can be defined as a dispute regarding a matter of legal or political facts in which the demands or statements of one party are rejected, countered or denied by the other party $\left[{ }^{28}\right]$. In public international law studies, there are 2 (two) types of disputes, namely legal or judicial disputes and political or non-judicial disputes. However, there are no clear and generally accepted criteria for the meaning of the two terms $\left[{ }^{29}\right]$. According to Oppenheim and Kelsen, there is no scientific justification and there is no basis for objective criteria that underlie the distinction between political and legal disputes. According to them, every dispute has a political aspect as well as a legal aspect. These disputes are usually related between sovereign states $\left[{ }^{30}\right]$.

Disputes can arise from various sources of potential disputes. Sources of potential disputes between countries can be in the form of borders, natural resources, environmental damage, trade and others. When this happens, international law plays an important role in resolve it $\left[{ }^{31}\right]$. The principle of promoting peaceful means in the resolution of international disputes was reaffirmed in the 1982 Manila Declaration on the Peaceful Resolution of International Disputes.

Delimitation of sea boundaries between coastal states ranks among the most difficult and controversial issues at the 3rd United Nations Conference on Maritime Law. The difficulty lies in finding and agreeing on clear and predictable rules of limitation and at the same time, enabling fairness to be achieved $\left[{ }^{32}\right]$. The 1982 UNCLOS succeeded in agreeing on international legal rules regarding national claims over the jurisdiction of countries at sea. The success of the 1982 UNCLOS was a culmination of efforts made since the 1958 Convention towards the expanding of jurisdiction of the coastal states. Specifically, the marine zone that can be claimed by the coastal State includes internal waters, territorial sea, archipelagic waters, contiguous zone, exclusive economic zone or ZEE and the continental shelf.

In international law, the claim to the jurisdiction of the State at sea by the coastal State is a unilateral act that does not require consent, but on the other hand there are special conditions in the provisions

${ }^{27}$ Huala Adolf, 2006, Op.Cit, p.1

28 J.G. Merrills, 1986, Penyelesaian Sengketa Internasional, Penyadur, Achmad Fauzan, Trasito, Bandung, p.1

${ }^{29}$ Huala Adlolf, 2006, Op Cit, p.3

${ }^{30}$ Ibid, p.5

${ }^{31}$ Ibid, p. 1

${ }^{32}$ Thomas Cottier, 2015, Equitable Principles of Maritime Boundary Delimitation: The Quest for Distributive Justice in International Law, Cambridge University Press, p.180 of international law that require mutual agreement on its borders with neighboring countries both opposite and side by side. This unilateral claim statement will not be a problem as long as other countries do not consider the action to interfere with their interests or sovereignty. The sea area that can be claimed by a coastal state can be seen as shown below.

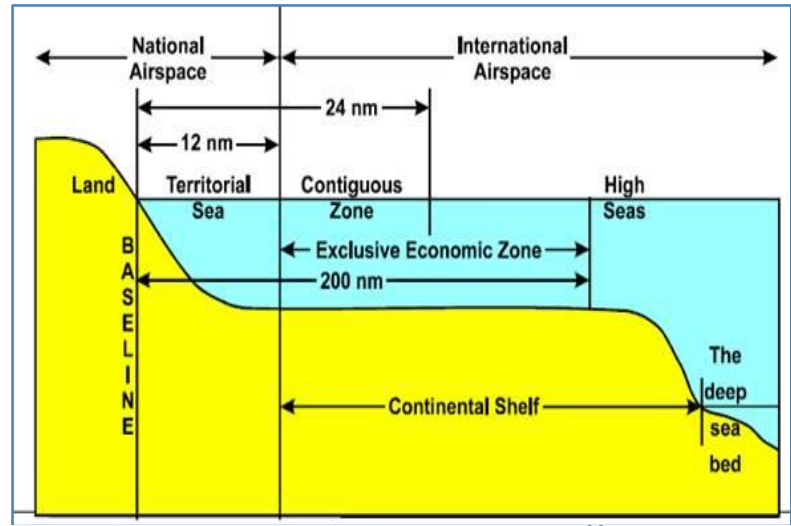

Fig-2: Sea territorial zone $\left[{ }^{33}\right]$

The claim of internal waters by a coastal State are regulated in Article 8 which states that internal waters are on the land side of the baseline of the territorial sea and constitute part of the internal waters of the coastal State. In the event that the stipulation of a straight baseline in accordance with the stipulated method results in the closure of internal waters, areas not previously considered to be such, then in such waters a right of peaceful passage will apply $\left[{ }^{34}\right]$. The State has full sovereignty over internal waters $\left[{ }^{35}\right]$ this sovereignty extends to the airspace on it, the seabed and the land beneath it $\left[{ }^{36}\right]$. A coastal State can fully exercise its sovereignty in internal waters as the exercise of sovereignty in mainland areas $\left[{ }^{37}\right]$. This shows the status of the coastal State' sovereignty in internal waters is identical to the sovereignty of the coastal State on the mainland, so if a foreign ship enters a port or other internal water territory, the ship is deemed to have entered the jurisdiction of the coastal state $\left[{ }^{38}\right]$.

By law, the right of peaceful passage is not permitted in internal waters. The exception to this principle is if the drawing of a straight baseline on the coastal area that juts into or there are small islands in front of the main island of the country, causes the water

33 Schofield, 2003, Maritime Zones and Jurisdictions, p.18 downloaded from www.gmat.unsw.edu.au/ablos/ABLOS03Folder/SESSI ON3.PDF on 15 March 2020.

${ }^{34}$ See, Article 8 paragraph (1 \& 2) UNCLOS 1982

${ }^{35}$ I Made Andi Arsana, 2007, Op Cit, p.27

${ }^{36}$ See Article 2 Paragraph (2) UNCLOS 1982

${ }^{37}$ Mangisi Simanjuntak, 2018, Konvensi PBB 1982 Tentang Hukum Laut Makna dan Manfaatnya Bagi Bangsas Indonesia, Mitra Wacana Media, Jakarta, p.18 ${ }^{38}$ Ibid, p19 
area that was not previously internal to become internal waters, then the right of peaceful passage in the internal waters will be remains applied $\left[{ }^{39}\right]$. In other words, if the waters were previously navigable by foreign ships and if the coastal State later changed the method of drawing their baselines, the foreign ships would still have the right of passage in a peaceful manner to pass in internal waters that were not part of internal waters previously.

In an archipelago State, the internal waters and around the country which are surrounded by archipelagic baselines have a special status. These waters are known as archipelagic waters. However, if an island within an archipelago has its own baseline, the waters that are inside the port or bay in the island can be called internal waters. The right of peaceful passage applies in archipelagic waters $\left[{ }^{40}\right]$. However, if necessary, an archipelagic state can stop the exercise of the right of peaceful passage in its archipelagic waters with security considerations. An island nation also has the responsibility to respect and guarantee the rights owned by the other countries which are established on the basis of official agreements $\left[{ }^{41}\right]$. This is regulated in Article 51 paragraph (1) UNCLOS 1982. Like traditional rights that must be respected.

In the case of overlapping claims by two or more coastal countries, delimitation of sea boundaries will be required $\left[{ }^{42}\right]$. Delimitation of sea boundaries is very important to ensure jurisdictional clarity and certainty $\left[{ }^{43}\right]$. Overlapping claims can occur in the territorial sea, ZEE and the continental shelf. The resolution of delimitation of sea areas due to overlapping claims for each of these zones is different in accordance with the provisions of applicable international law.

The application of archipelagic baselines by Indonesia makes the Indonesian archipelagic waters larger than all other archipelagic States $\left[{ }^{44}\right]$. Indonesia also has the same problems as India and Thailand regarding ZEE and the continental shelf. On the other hand, the problem of Indonesia with Timor Lesta are related to the baseline in the establishment of archipelagic baselines between the two countries and the expansion of archipelagic waters by Indonesia which closed the ZEE which was expanded by Palau, causing overlapping claims.

\footnotetext{
${ }^{39}$ Etty R. Agoes, 1991, Konvensi Hukum Laut 1982, Masalah Pengaturan Hal Lintas Kapal Asing, Abardin, Bandung, p.1

${ }^{40}$ See Article 52 Paragraph (2) UNCLOS 1982

${ }^{41}$ I Made Andi Arsana, 2007, Op Cit, p.28

${ }^{42}$ I Made Andi Arsana, 2007, Op Cit, p.40

${ }^{43}$ Ibid, p. 1

${ }^{44}$ Kevin Baumert, OP Cit, p.62
}

Based on the provisions of international maritime law, Indonesia has the right to draw archipelagic baselines, because as an archipelagic country Indonesia has the right to use archipelago baselines to accommodate its geographical form. Indonesia also has the right to apply archipelago baselines to determine the points of archipelagic baselines in order to close archipelagic waters. Considering that the problem of defining the delimitation of a country' maritime territory is a unilateral measure by the State, but if there are objections it must be resolved by agreement $\left[{ }^{45}\right]$.

On the other hand, the mechanism to resolve delimitation of sea territory through negotiations or international courts must be based on the equitable principle to achieve an equitable solution. To ensure an equitable solution again depends on the parties, if the parties agree with the delimitation result, it can be considered a fair solution $\left[{ }^{46}\right]$. On the other hand, the application of an equidistance line as a temporary basis and taking into account the relevant/special circumstances is an option for determining the delimitation of boundaries which can be a method with the agreement of the parties to achieve a fair solution.

The consideration of relevant and special circumstances refers to the consideration of geographical aspects that play a decisive role in delimiting the boundaries of the sea area compared to social, economic, technological and environmental aspects. This can be seen in the decision of the International Court of Justice in the case of the Gulf of Maine which rejected the parties' reasons for considering the dependence of border coastal communities on fishery resources. For Indonesia, in negotiating the delimitation of overlapping marine areas, it is important to consider the aspects of the resolution as described above, the position as an archipelago state with a long coastline with such large marine resources can provide great benefits for the country. However, determination of delimitation of border areas that are still problematic is not easy to see the disadvantages caused by the application of the baseline of the Indonesian archipelago to the sovereignty and security of neighboring countries, so need to compromise. Compromise must be based on the principles of international law, namely the principle of fairness for a just solution.

\footnotetext{
${ }^{45}$ Andi Arsana, 2004, Challenges and Opportunities In The Delimitation Of Indonesia's Maritime Boundaries: A Legal And Technical Approach, University of Wollongong Research Online, p. 8. s

${ }^{46}$ Jan Schneider, 1985, The Gulf of Maine Case: The Nature of an Equitable Result, American Jurnal of International Law, Col. 79, No. 3, p.472
} 


\section{CONCLUSION}

Sovereignty claim of Indonesia as an archipelagic country over the delimitation of sea territories, it can be concluded that the claim of sea borders by a State in practice is a manifestation of territorial sovereignty. Sea borders are a complex subject for an archipelago such as Indonesia. Unilateral claims are needed to establish Indonesia's position in areas that are considered to be its sovereignty. Efforts to claim the sovereignty of Indonesia' maritime boundaries as an archipelagic country have been done since the beginning of independence, marked by the 1957 Djuanda Declaration until it was agreed nationally to the official map of Indonesia in 2017. The unilateral claim of Indonesia for delimiting sea boundaries with neighboring countries is an act that has legal legality, because it is done based on the provisions of the convention.

The construction of dispute resolution over overlapping claims on the borders of Indonesia' maritime territory with neighboring countries, it can be concluded that the determination of delimitation of sea territory between archipelagic countries such as Indonesia and coastal States must provide a just solution for countries. In determining the delimitation of sea boundaries between archipelagic countries such as Indonesia and neighboring countries, it must be based on the fairness principle by considering political, legal and technical aspects in order to achieve an equitable solution while still considers special or relevant circumstances. 